\title{
Serum 25-Hydroxyvitamin D Levels and Prognosis in Hematological Malignancies: A Systematic Review and Meta-Analysis
}

\author{
Wei Wang ${ }^{a}$ Guangyun Li $^{a} \quad$ Xiaoyan He $\mathrm{H}^{\mathrm{b}}$ Jian Gao ${ }^{c}$ Robin Wang ${ }^{\mathrm{d}}$ Yangang Wang ${ }^{\mathrm{d}}$ \\ Wenjuan Zhao ${ }^{d}$ \\ a'Department of Hematology, Affiliated Hospital of Qingdao University, Qingdao, bepartment of \\ Oncology, People's Hospital of Ganzhou, Ganzhou, 'Department of Pediatrics, Maternal and Child \\ Health Hospital of Weifang, Weifang, dDepartment of Endocrinology, Affiliated Hospital Qingdao \\ University, Qingdao, China
}

\section{Key Words}

25-hydroxyvitamin D $\cdot$ Leukemia $・$ Lymphoma $・$ Survival

\begin{abstract}
Background/Aims: Serum 25-hydroxyvitamin D [25(OH)D] levels proved to be associated with prognosis of patients with colorectal cancer or breast cancer, but its prognostic role in hematological malignancies was still unclear. A systematic review and meta-analysis was performed to comprehensively evaluate the association between serum 25(OH)D levels and prognosis of patients with hematological malignancies. Methods: We searched Pubmed, Embase, Web of Science, and Google Scholar for studies evaluating the association between serum $25(\mathrm{OH}) \mathrm{D}$ levels and prognosis of patients with hematological malignancies. The hazard ratios (HR) with $95 \%$ confidence intervals $(95 \% \mathrm{CI})$ for overall survival (OS) or relapse-free survival (RFS) were pooled using meta-analysis. Results: Seven studies with a total of 2,643 patients with hematological cancer were finally included into the meta-analysis. Overall, compared with normal serum 25(OH)D levels, low serum 25(OH)D levels were significantly associated with both poorer OS (HR $=1.85,95 \% \mathrm{CI} 1.54-2.23, \mathrm{P}<0.001)$ and poorer RFS (HR = $1.45,95 \%$ CI 1.25 to $1.70, \mathrm{P}<0.001$ ) in hematological malignancies. Subgroup analysis further showed that low serum 25(OH)D levels were significantly associated with poorer OS and RFS in both lymphoma and leukemia. Conclusion: Low serum 25(OH)D levels are significantly associated with poorer prognosis in patients with hematological malignancies including lymphoma and leukemia.
\end{abstract}

W. Wang and G. Li contrbuted equally to the study.

Yangang Wang, MD,

Wenjuan Zhao,
Department of Endocrinology, Affiliated Hospital of Qingdao University,

16 Jiangsu Road, Qingdao 266003 (China)

E-Mail nlwang@126.com, E-Mail zhaowjqdu@yeah.net 


\section{Cellular Physiology Cell Physiol Biochem 2015;35:1999-2005 \begin{tabular}{l|l} 
and Biochemistry Published onlIne: IVarch 27, 2015 & $\begin{array}{l}\text { C) 2015 S. Karger AG, Basel } \\
\text { www.karger.com/cpb }\end{array}$ \\
\hline
\end{tabular}}

Wang et al.: Vitamin D and Hematological Malignancies

\section{Introduction}

Hematological malignancies mainly include leukemia, lymphoma, and myeloma [1, $2]$. There were about 140,000 new cases of hematological malignancies and 53,010 deaths due to hematological malignancies projected to occur in 2014 in USA [3]. There are many advances in the treatments of leukemia and lymphoma in recent years, but the overall survival for patients with leukemia or lymphoma has not been improved obviously $[1,2]$. Identification of prognostic factors for leukemia or lymphoma is very helpful for clinicians to choose best therapeutic strategies for patients and improve their prognosis [2, 4]. In addition, identification of prognostic factors for leukemia or lymphoma is also helpful for us to get a better understanding of the pathogenesis of leukemia and lymphoma. However, there is lack of effective and popularized prognostic factors for hematological malignancies, and relevant researches are very necessary $[2,4]$. Vitamin $D$ is not really a vitamin but a multifunctional pro-hormone and has widespread actions in human bodies $[5,6]$. The 25-hydroxyvitamin $D$ $[25(\mathrm{OH}) \mathrm{D}]$ is the circulating form of the hormone that is measured in the blood and clinically used to establish and monitor patients' vitamin D status [5]. Recent studies have demonstrated that 25(OH)D also has some effects on cell differentiation, proliferation, and apoptosis [5]. Serum 25(OH)D levels proved to be associated with prognosis of patients with colorectal cancer or breast cancer $[7,8]$, but its prognostic role in hematological malignancies was still unclear. Though there were several studies published to assess the association between serum 25(OH)D levels and prognosis of patients with leukemia or lymphoma, they reported contradictory results [9-12]. We thus perform a systematic review and meta-analysis aiming to comprehensively evaluate the association between serum 25(OH)D levels and prognosis of patients with hematological malignancies.

\section{Materials and Methods}

\section{Search strategy}

We searched Pubmed, Embase, Web of Science, and Google Scholar for studies evaluating the association between serum 25(OH)D levels and prognosis of patients with hematological malignancies. The time for literature search was from their inception through May 26, 2014. An updated literature was performed on November 28, 2014. We used the combination of search terms for 25(OH)D and hematological malignanceies: ("Vitamin D" or "25-hydroxyvitamin D" or “25(OH)D") and ("hematological malignancies" or "leukemia" or "lymphoma" or "myeloma"). There was no language limitation in our search. All references cited in those included studies or relevant reviews were further retrieved for other potential studies not indexed in the common databases.

\section{Inclusion criteria}

To be included into the meta-analysis, eligible studies must meet the following inclusion criteria: (1) Cohort studies evaluating the association between serum 25(OH)D levels and prognosis of patients with hematological malignancies; (2) Patients had leukemia, lymphoma, myeloma, or other hematological malignancies; (3) Report hazard ratios (HR) or risk ratios (RR) with 95\% confidence intervals (95\%CI) of overall survival (OS; date of treatment to date of death as a result of any cause) and relapse-free survival (RFS; date of treatment to date of first recurrence or death) according to serum 25(OH)D levels. Review articles, editorials, and case reports were not included. We also excluded studies in which no HRs or RRs were available or could be calculated for other types of data. For multiple publications from the same institution with identical or overlapping patient cohorts, only the study with the largest data set was included.

\section{Data extraction and quality assessment}

Two investigators performed the data extraction independently using a standardized sheet of Excel. For the existence of disagreements, they were resolved through consensus. The data extracted from included studies were as the following: first author, publication year, study design, patients' recruitment time, types of hematological malignancies, time of follow-up, adjusted factors, and HR estimations. We extracted the 
most adjusted HRs when several adjusted HRs were available. Quality assessment of included studies was assessed using the Newcastle Ottawa scale (NOS). Studies with 7 or more stars were considered as high quality.

\section{Statistical analysis}

The HRs with 95\%CIs for OS or RFS were pooled using meta-analysis, and an HR greater than 1 indicated a worse prognosis in patients with low serum 25(OH)D levels. The significance of the pooled HR was determined by the $\mathrm{Z}$ test, and a P value of less than 0.05 was considered statistically significant. The $\mathrm{I}^{2}$ statistic to quantify the proportion of the total variation due to heterogeneity was used assess the heterogeneity [13]. The $\mathrm{I}^{2}$ value ranged from $0 \%$ to $100 \%$. An $\mathrm{I}^{2}$ of 0 to $25 \%$ indicated no heterogeneity, 25 to $50 \%$ indicated moderate heterogeneity, 50 to $75 \%$ indicated large heterogeneity, 75 to $100 \%$ indicated extreme heterogeneity [13]. If large heterogeneity or extreme heterogeneity existed, the random-effects model (DerSimonian and Laird method) was used to pool the results [14]. If no heterogeneity or moderate heterogeneity existed, the fixed-effect model (Mantel-Haenszel method) was used to pool the results [15]. To validate the credibility of outcomes in this meta-analysis, sensitivity analysis was performed by sequential omission of individual studies. Subgroup analysis was performed by types of hematological malignancies, such as leukemia and lymphoma. Potential publication bias was assessed by visual inspection of the funnel plots, and an asymmetric plot suggested risk of publication bias. Egger linear regression test was also used to assess publication bias, and a P value less than 0.05 indicated high risk of publication bias [16]. All analyses were performed using STATA version 12.0 (Stata Corp, College Station, TX, USA). A P value $<0.05$ was considered statistically significant.

\section{Results}

\section{Study characteristics}

Though a total of 503 individual abstracts were identified through literature search, but only 9 studies were preliminarily included and assessed by reading full-text [9-12, 17-22]. Three studies were further excluded after reading full-text [19-21], and seven studies were finally included into the meta-analysis [9-12, 17, 18, 22]. Those seven studies involved a total of 2,643 patients with hematological cancer $[9-12,17,18,22]$. The main characteristics of those seven eligible studies were shown in Table 1. All seven studies were prospective cohort studies, and were published in English [9-12, 17, 18, 22]. According to the quality criteria of NOS scale, all seven studies were high-quality studies (Table 1). There were four studies on lymphoma $[9,10,18,22]$, three studies on leukemia [10-12], and one study on

Table 1.The characteristics of six cohort studies in the meta-analysis. (§OS was for overall survival, while RFS was for relapse-free survival)

\begin{tabular}{|c|c|c|c|c|c|c|c|}
\hline Study authors & $\begin{array}{l}\text { Study } \\
\text { design }\end{array}$ & $\begin{array}{l}\text { Recruitment } \\
\text { time }\end{array}$ & Patients & $\begin{array}{l}\text { Definition } \\
\text { of low } \\
\text { serum } \\
25(\mathrm{OH}) \mathrm{D} \\
\text { levels }\end{array}$ & $\begin{array}{l}\text { Follow } \\
\text { up } \\
\text { (median } \\
\text { time) }\end{array}$ & Outcomes§ & $\begin{array}{l}\text { Quality } \\
\text { scores }\end{array}$ \\
\hline $\begin{array}{l}\text { Drake MT } 2010 \\
\text { [9] }\end{array}$ & $\begin{array}{l}\text { Prospective } \\
\text { cohort }\end{array}$ & $2002-2008$ & $\begin{array}{l}983 \text { subjects with } \\
\text { non-Hodgkin's } \\
\text { lymphoma }\end{array}$ & $\begin{array}{l}\text { Lower than } \\
25 \mathrm{ng} / \mathrm{mL}\end{array}$ & $\begin{array}{l}34.8 \\
\text { moths }\end{array}$ & OS; RFS & 9 \\
\hline $\begin{array}{l}\text { Shanafelt TD } \\
2011[12]\end{array}$ & $\begin{array}{l}\text { Prospective } \\
\text { cohort }\end{array}$ & $\begin{array}{l}2002-2008 \\
\text { and } 1994- \\
2002\end{array}$ & $\begin{array}{l}390 \text { chronic } \\
\text { lymphocytic } \\
\text { leukemia patients } \\
\text { and another cohort } \\
\text { of } 159 \text { patients with } \\
\text { chronic lymphocytic } \\
\text { leukemia }\end{array}$ & $\begin{array}{l}\text { Lower than } \\
25 \mathrm{ng} / \mathrm{mL}\end{array}$ & $\begin{array}{l}36 \\
\text { months }\end{array}$ & OS; RFS & 9 \\
\hline $\begin{array}{l}\text { Pardanani A } \\
2011 \text { [17] }\end{array}$ & $\begin{array}{l}\text { Prospective } \\
\text { cohort }\end{array}$ & Not available & $\begin{array}{l}247 \text { patients with } \\
\text { primary } \\
\text { myelofibrosis and } 74 \\
\text { patients with } \\
\text { myelodysplastic } \\
\text { syndromes }\end{array}$ & $\begin{array}{l}\text { Lower than } \\
25 \mathrm{ng} / \mathrm{mL}\end{array}$ & $\begin{array}{l}34 \\
\text { months }\end{array}$ & OS; RFS & 8 \\
\hline $\begin{array}{l}\text { Tretli S } 2012 \\
{[18]}\end{array}$ & $\begin{array}{l}\text { Prospective } \\
\text { cohort }\end{array}$ & $1984-2004$ & $\begin{array}{l}145 \text { patients with } \\
\text { lymphoma }\end{array}$ & $\begin{array}{l}\text { Lower than } \\
18 \mathrm{ng} / \mathrm{mL}\end{array}$ & $\begin{array}{l}\text { About } 3 \\
\text { years }\end{array}$ & os & 7 \\
\hline $\begin{array}{l}\text { Aref S } 2013 \\
{[10]}\end{array}$ & $\begin{array}{l}\text { Prospective } \\
\text { cohort }\end{array}$ & Not available & $\begin{array}{l}75 \text { patients with } \mathrm{B} \\
\text { chronic lymphocytic } \\
\text { leukemia, and } 120 \\
\text { patients with non- } \\
\text { Hodgkin's lymphoma }\end{array}$ & $\begin{array}{l}\text { Lower than } \\
20 \mathrm{ng} / \mathrm{mL}\end{array}$ & $\begin{array}{l}\text { About } 5 \\
\text { years }\end{array}$ & os & 8 \\
\hline $\begin{array}{l}\text { Lee HJ } 2014 \\
\text { [11] }\end{array}$ & $\begin{array}{l}\text { Prospective } \\
\text { cohort }\end{array}$ & Not available & $\begin{array}{l}97 \text { patients with } \\
\text { acute myeloid } \\
\text { leukemia }\end{array}$ & $\begin{array}{l}\text { Lower than } \\
20 \mathrm{ng} / \mathrm{mL}\end{array}$ & $\begin{array}{l}15.6 \\
\text { months }\end{array}$ & OS; RFS & 8 \\
\hline $\begin{array}{l}\text { Bittenbring JT } \\
2014[22]\end{array}$ & $\begin{array}{l}\text { Prospective } \\
\text { cohort }\end{array}$ & $2000-2005$ & $\begin{array}{l}359 \text { patients with } \\
\text { diffuse large } \\
\text { B-cell lymphoma }\end{array}$ & $\begin{array}{l}\text { Lower than } \\
8 \mathrm{ng} / \mathrm{mL}\end{array}$ & $\begin{array}{l}\text { About } 3 \\
\text { years }\end{array}$ & OS; RFS & 9 \\
\hline
\end{tabular}


Fig. 1. Low serum $25(\mathrm{OH})$ D levels were associated with poorer overall survival in patients with hematological malignancies.

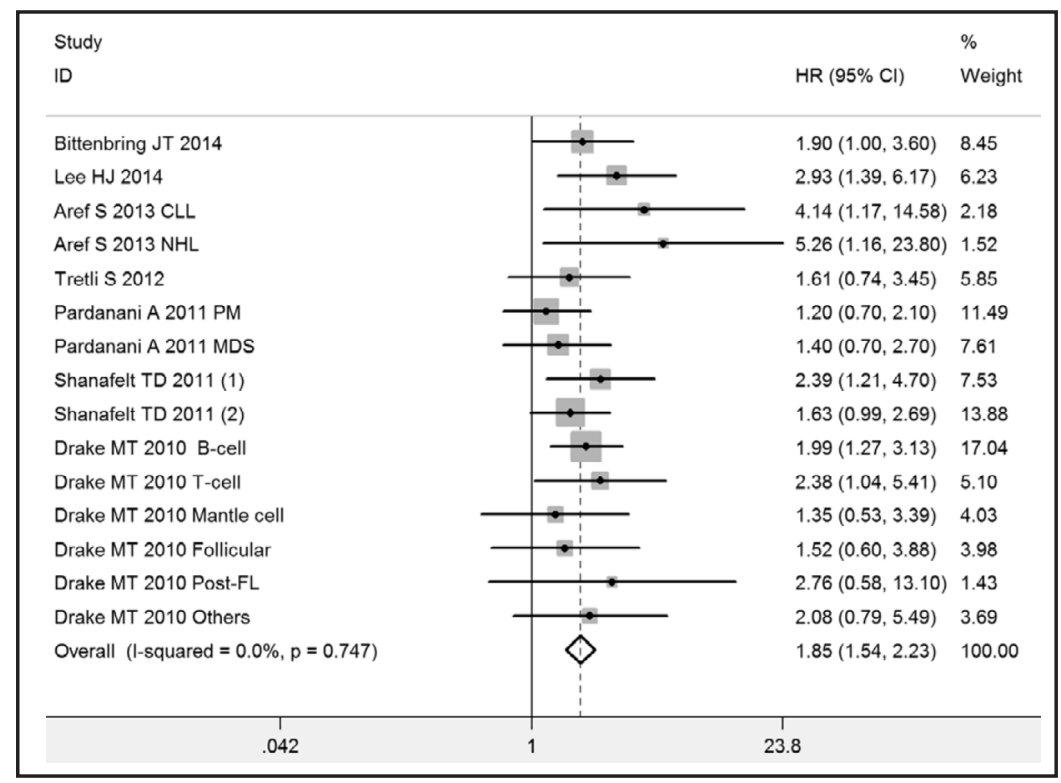

Fig. 2. Low serum $25(\mathrm{OH})$ D levels were associated with poorer recurrence-free survival in patients with hematological malignancies.

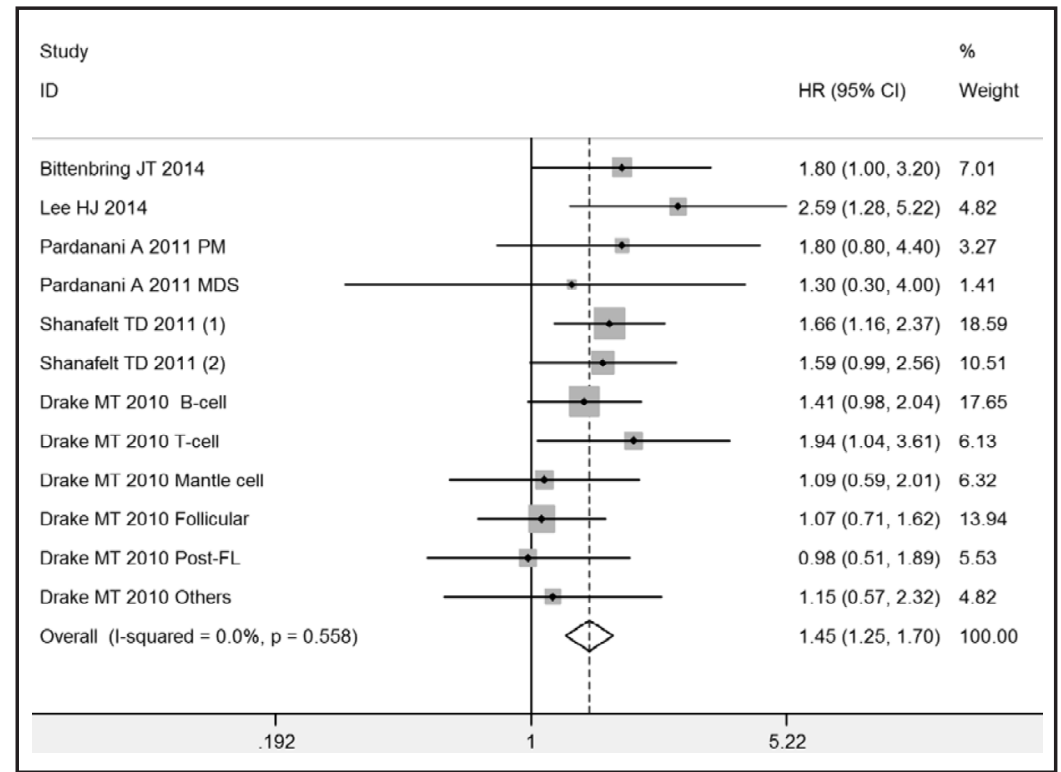

primary myelofibrosis and myelodysplastic syndromes [17]. All seven studies reported the adjusted HRs of OS, and four studies reported the adjusted HRs of DFS (Table 1). Drake et al. reported the outcomes for five subtypes of lymphoma, and was extracted as five individual studies [9]. Three studies reported two different studies, and thus were extracted as two separate studies, respectively $[10,12,17]$.

\section{$25(\mathrm{OH}) \mathrm{D}$ levels and overall survival}

There was no heterogeneity existing in those included studies reporting adjusted HRs of OS, and the fixed-effect model was used to pool the results $\left(\mathrm{I}^{2}=0 \%\right)$. Overall, compared with normal serum 25(OH)D levels, low serum 25(OH)D levels were significantly associated with poorer OS $(\mathrm{HR}=1.85,95 \%$ CI 1.54-2.23, $\mathrm{P}<0.001)$ in patients with hematological malignancies (Fig. 1). Sensitivity analysis by sequential omission of individual studies didn't significantly alter the pooled HRs. Subgroup analysis showed that low serum 25(OH)D levels were significantly associated with poorer OS in both lymphoma patients (HR $=1.95,95 \% \mathrm{CI}$ 1.47-2.59, $\left.\mathrm{P}<0.001, \mathrm{I}^{2}=0 \%\right)$ and leukemia patients $(\mathrm{HR}=2.17,95 \% \mathrm{CI} 1.54-3.05, \mathrm{P}<0.001$, $\left.\mathrm{I}^{2}=0 \%\right)$. 
$25(\mathrm{OH})$ D levels and relapse-free survival

There was no heterogeneity existing in those included studies reporting adjusted HRs of RFS, and the fixed-effect model was used to pool the results $\left(\mathrm{I}^{2}=0 \%\right)$. Overall, compared with normal serum 25(OH)D levels, low serum 25(OH)D levels were significantly associated with poorer RFS (HR $=1.45,95 \%$ CI 1.25 to $1.70, \mathrm{P}<0.001)$ in patients with hematological malignancies (Fig. 2). Sensitivity analysis by sequential omission of individual studies didn't significantly alter the pooled HRs. Subgroup analysis also showed that low serum 25(OH)D levels were significantly associated with poorer RFS in both lymphoma patients (HR $=1.25$, $95 \%$ CI 1.02-1.54, $\left.\mathrm{P}=0.036, \mathrm{I}^{2}=0 \%\right)$ and leukemia patients $(\mathrm{HR}=1.74,95 \% \mathrm{CI} 1.34-2.27$, $\left.\mathrm{P}<0.001, \mathrm{I}^{2}=0 \%\right)$.

\section{Publication bias}

The shape of funnel plots in the meta-analysis relating OS and RFS did not show obvious evidence of asymmetry. The P values of Egger's test in the meta-analysis relating OS and RFS were 0.47 and 0.88 , which suggested that there was no obvious risk of publication bias in the meta-analysis. Thus, there was no obvious risk of publication bias in the meta-analysis.

\section{Discussion}

In present study, we performed a systematic review and meta-analysis aiming to comprehensively evaluate the association between serum 25(OH)D levels and prognosis of patients with hematological malignancies. To the best of our knowledge, it's the first metaanalysis on the prognostic role of serum 25(OH)D levels in patients with hematological malignancies. Six studies with a total of 2,284 patients with hematological cancer were finally included into the meta-analysis [9-12, 17, 18, 22]. The findings from the meta-analysis suggest that low serum 25(OH)D levels are significantly associated with poorer prognosis in patients with hematological malignancies, including lymphoma and leukemia. Thus, the meta-analysis provides new evidence for the prognostic role of serum 25(OH)D levels in patients with hematological malignancies.

Currently, there are a number of studies published to assess the association between serum $25(\mathrm{OH}) \mathrm{D}$ levels and prognosis of patients with cancer $[7,9,11,12,18,20,23]$. The prognostic role of serum 25(OH)D levels has been found in two types of cancers including colorectal cancer and breast cancer, but its role in other types of cancers is still unclear. In present meta-analysis, our findings provide strong evidence for the prognostic role of serum 25(OH)D levels in patients with lymphoma or leukemia. Thus, the findings from the study add new evidence for the anti-cancer effects and prognostic roles of 25(OH)D in cancer patients.

It has been well accepted that vitamin $\mathrm{D}$ is not really a vitamin but a precursor of potent steroid hormones and has widespread actions throughout human body [24-27]. The anticancer effects of vitamin D have been largely investigated in the past decade [5, 26]. Previous studies have demonstrated that 25(OH)D has important effects on cell differentiation, proliferation, and apoptosis, and thus has anti-cancer effects [5,27]. It has also been suggested that vitamin $\mathrm{D}$ can inhibit the proliferation and induce the differentiation of lymphocytes and lymphoma cell lines [27-29]. Thus, there is biological evidence for the preventive effect of vitamin D against lymphoma or leukemia. Two epidemiological studies also have shown some possible adverse association between serum 25(OH)D levels and risks of leukemia or lymphoma [30, 31].

Although epidemiological studies have suggested that vitamin D deficiency increases the risk of developing cancer and results in poor prognosis in cancer patients, there is lack of clinical trials investigating the efficacy of vitamin D supplements in improving cancer prognosis [6]. It's also still unknown whether vitamin D supplementation in patients with newly diagnosed leukemia or lymphoma and low 25(OH)D levels can lead to improved outcomes, and that needs further investigation. Considering the important and obvious 


\section{Cellular Physiology Cell Physiol Biochem 2015;35:1999-2005 \begin{tabular}{ll|l} 
and $10.1159 / 000374007$ & \\
and Biochemistry & $\begin{array}{l}\text { O 2015 S. Karger AG, Basel } \\
\text { www.karger.com/cpb }\end{array}$ \\
\cline { 2 - 3 }
\end{tabular}}

Wang et al.: Vitamin D and Hematological Malignancies

prognostic role of low serum 25(OH)D levels in lymphoma and leukemia, clinical trials may be performed to evaluate the effect of vitamin D supplements on the survival of patients with lymphoma or leukemia. However, there was no evidence from clinical trials aiming to assess the effect of vitamin D supplements on survival of cancers. Further trials are needed to assess the effect of vitamin D supplements on the survival of patients with hematological malignancies.

There were several limitations to be considered when interpreting the findings from the meta-analysis. Firstly, there were only six included studies in the meta-analysis. Though we did not observe an obvious risk of publication bias in the meta-analysis, the limited number of included studies may decrease the power of funnel plot and Egger test in detecting the risk of publication bias. Thus, more prospective cohort studies are needed to validate the findings from the meta-analysis. Secondly, owing to the limited number of included studies, we didn't perform further subgroup analysis by the histological subtypes of lymphoma or leukemia. Though we fount that low serum 25(OH)D levels were significantly associated with poorer OS and RFS in patients with lymphoma and in those with leukemia, the prognostic role of serum 25(OH)D levels may not generalize to all histological subtypes of lymphoma or leukemia. Thus, more studies are needed to further assess the prognostic role of serum 25(OH)D levels in patients with different histological subtypes of lymphoma or leukemia. Finally, we were also unable to analyze the prognostic role of serum 25(OH)D levels of patients receiving different treatments. Serum 25(OH)D levels may have different prognostic roles in patients receiving different treatments, and it need future studies.

In conclusion, compared with normal serum 25(OH)D levels, low serum 25(OH)D levels are significantly associated with poorer prognosis in patients with hematological malignancies. Besides, more prospective cohort studies are needed to validate the findings from the meta-analysis. Clinical trials may also be performed to evaluate the effect of vitamin D supplements on the survival of patients with lymphoma or leukemia.

\section{Acknowledgments}

We thank Dr. Sun from Nanjing Medical University for his kind help in the statistics. There was no funding source for this study.

\section{Disclosure Statement}

We declare that we have no conflicts of interest.

\section{References}

1 Shankland KR, Armitage JO, Hancock BW: Non-hodgkin lymphoma. Lancet 2012;380:848-857.

$\checkmark 2$ Byrd JC, Jones JJ, Woyach JA, Johnson AJ, Flynn JM: Entering the era of targeted therapy for chronic lymphocytic leukemia: Impact on the practicing clinician. J Clin Oncol 2014

3 Siegel R, Ma J, Zou Z, Jemal A: Cancer statistics, 2014. CA Cancer J Clin 2014;64:9-29.

4 Ghanem H, Tank N, Tabbara IA: Prognostic implications of genetic aberrations in acute myelogenous leukemia with normal cytogenetics. Am J Hematol 2012;87:69-77.

5 Feldman D, Krishnan AV, Swami S, Giovannucci E, Feldman BJ: The role of vitamin d in reducing cancer risk and progression. Nat Rev Cancer 2014;14:342-357.

6 Bolland MJ, Grey A, Gamble GD, Reid IR: The effect of vitamin d supplementation on skeletal, vascular, or cancer outcomes: A trial sequential meta-analysis. Lancet Diabetes Endocrinol 2014;2:307-320.

7 Maalmi H, Ordonez-Mena JM, Schottker B, Brenner H: Serum 25-hydroxyvitamin d levels and survival in colorectal and breast cancer patients: Systematic review and meta-analysis of prospective cohort studies. Eur J Cancer 2014;50:1510-1521.

8 Wang B, Jing Z, Li C, Xu S, Wang Y: Blood 25-hydroxyvitamin d levels and overall mortality in patients with colorectal cancer: A dose-response meta-analysis. Eur J Cancer 2014;50:2173-2175. 


\section{Cellular Physiology Cell Physiol Biochem 2015;35:1999-2005 \begin{tabular}{ll|l} 
and Biochemistry Published onIIne: IVarch 27, 2015 & $\begin{array}{l}\text { C) 2015 S. Karger AG, Basel } \\
\text { www.karger.com/cpb }\end{array}$ \\
\hline
\end{tabular}}

Wang et al.: Vitamin D and Hematological Malignancies

-9 Drake MT, Maurer MJ, Link BK, Habermann TM, Ansell SM, Micallef IN, Kelly JL, Macon WR, Nowakowski GS, Inwards DJ, Johnston PB, Singh RJ, Allmer C, Slager SL, Weiner GJ, Witzig TE, Cerhan JR: Vitamin d insufficiency and prognosis in non-hodgkin's lymphoma. J Clin Oncol 2010;28:4191-4198.

10 Aref S, Ibrahim L, Azmy E: Prognostic impact of serum 25-hydroxivitamin d [25(oh)d] concentrations in patients with lymphoid malignancies. Hematology 2013;18:20-25.

11 Lee HJ, Muindi JR, Tan W, Hu Q Wang D, Liu S, Wilding GE, Ford LA, Sait SN, Block AW, Adjei AA, Barcos M, Griffiths EA, Thompson JE, Wang ES, Johnson CS, Trump DL, Wetzler M: Low 25(oh) vitamin d3 levels are associated with adverse outcome in newly diagnosed, intensively treated adult acute myeloid leukemia. Cancer 2014;120:521-529.

12 Shanafelt TD, Drake MT, Maurer MJ, Allmer C, Rabe KG, Slager SL, Weiner GJ, Call TG, Link BK, Zent CS, Kay NE, Hanson CA, Witzig TE, Cerhan JR: Vitamin d insufficiency and prognosis in chronic lymphocytic leukemia. Blood 2011;117:1492-1498.

13 Higgins JP, Thompson SG, Deeks JJ, Altman DG: Measuring inconsistency in meta-analyses. BMJ 2003;327:557-560.

14 DerSimonian R, Laird N: Meta-analysis in clinical trials. Control Clin Trials 1986;7:177-188.

15 Mantel N, Haenszel W: Statistical aspects of the analysis of data from retrospective studies of disease. J Natl Cancer Inst 1959;22:719-748.

16 Egger M, Davey Smith G, Schneider M, Minder C: Bias in meta-analysis detected by a simple, graphical test. BMJ 1997;315:629-634.

17 Pardanani A, Drake MT, Finke C, Lasho TL, Rozell SA, Jimma T, Tefferi A: Vitamin d insufficiency in myeloproliferative neoplasms and myelodysplastic syndromes: Clinical correlates and prognostic studies. Am J Hematol 2011;86:1013-1016.

-18 Tretli S, Schwartz GG, Torjesen PA, Robsahm TE: Serum levels of 25-hydroxyvitamin d and survival in norwegian patients with cancer of breast, colon, lung, and lymphoma: A population-based study. Cancer Causes Control 2012;23:363-370.

19 Badros A, Goloubeva O, Terpos E, Milliron T, Baer MR, Streeten E: Prevalence and significance of vitamin d deficiency in multiple myeloma patients. Br J Haematol 2008;142:492-494.

$20 \mathrm{Ng} \mathrm{AC}$, Kumar SK, Rajkumar SV, Drake MT: Impact of vitamin d deficiency on the clinical presentation and prognosis of patients with newly diagnosed multiple myeloma. Am J Hematol 2009;84:397-400.

21 Thomas X, Chelghoum Y, Fanari N, Cannas G: Serum 25-hydroxyvitamin d levels are associated with prognosis in hematological malignancies. Hematology 2011;16:278-283.

-22 Bittenbring JT, Neumann F, Altmann B, Achenbach M, Reichrath J, Ziepert M, Geisel J, Regitz E, Held G, Pfreundschuh M: Vitamin D deficiency impairs rituximab-mediated cellular cytotoxicity and outcome of patients with diffuse large B-cell lymphoma treated with but not without rituximab. J Clin Oncol 2014;32:3242-3248.

23 Toriola AT, Nguyen N, Scheitler-Ring K, Colditz GA: Circulating 25-hydroxyvitamin d levels and prognosis among cancer patients: A systematic review. Cancer Epidemiol Biomarkers Prev 2014;23:917-933.

24 Bolland MJ, Grey A, Gamble GD, Reid IR: Vitamin D supplementation and falls: a trial sequential metaanalysis.Lancet Diabetes Endocrinol 2014;2:573-580.

25 Bolland MJ, Grey A, Gamble GD, Reid IR: The effect of vitamin D supplementation on skeletal, vascular, or cancer outcomes: a trial sequential meta-analysis.Lancet Diabetes Endocrinol 2014; 2: 307-320.

26 Autier P, Boniol M, Pizot C, Mullie P: Vitamin D status and ill health: a systematic review. Lancet Diabetes Endocrinol 2014;2:76-89.

27 Guo J, Xia N, Yang L, Zhou S, Zhang Q, Qiao Y, Liu Z: Gsk-3beta and vitamin d receptor are involved in betacatenin and snail signaling in high glucose-induced epithelial-mesenchymal transition of mouse podocytes. Cell Physiol Biochem 2014;33:1087-1096.

28 Luong QT, Koeffler HP: Vitamin d compounds in leukemia. J Steroid Biochem Mol Biol 2005;97:195-202.

29 Hickish T, Cunningham D, Colston K, Millar BC, Sandle J, Mackay AG, Soukop M, Sloane J: The effect of 1,25-dihydroxyvitamin d3 on lymphoma cell lines and expression of vitamin d receptor in lymphoma. Br J Cancer 1993;68:668-672.

30 Provvedini DM, Tsoukas CD, Deftos LJ, Manolagas SC: 1,25-dihydroxyvitamin d3 receptors in human leukocytes. Science 1983;221:1181-1183.

-31 Lim U, Freedman DM, Hollis BW, Horst RL, Purdue MP, Chatterjee N, Weinstein SJ, Morton LM, Schatzkin A, Virtamo J, Linet MS, Hartge P, Albanes D: A prospective investigation of serum 25-hydroxyvitamin d and risk of lymphoid cancers. Int J Cancer 2009;124:979-986. 